\title{
Convergent evolution of pollen transport mode in two distantly related bee genera (Hymenoptera: Andrenidae and Melittidae)
}

\author{
Zachary M. PortMAn, Vincent J. TEPEDINO \\ Department of Biology, Utah State University, Logan, UT 84322-5305, USA
}

Received 31 July 2016 - Revised 11 December 2016 - Accepted 28 December 2016

\begin{abstract}
Purposeful transport of pollen represents a key innovation in the evolution of bees from predatory wasps. Most bees transport pollen on specialized hairs on the hind legs or ventral metasoma in one of three ways: moist, dry, or "glazed," which combines dry and moist transport. The evolutionary pathway among these three transport modes is unclear, though dry transport has been hypothesized to be ancestral. We address this hypothesis using museum specimens and published records of the bee genera Perdita (Andrenidae) and Hesperapis (Melittidae), two distantly related groups whose pollen transport modes appear to have converged. Most species in both genera transport moistened pollen; glazed and dry transport are limited to derived clades of specialists on floral hosts in Asteraceae and Onagraceae, with specialization on Asteraceae associated with more elaborate scopal hairs. The associations between transport mode, host plant, and hair type may be due to the sticky pollenkitt of asteraceous pollen grains and the viscin threads of Onagraceae pollen, which provide alternates to the binding properties of nectar. These findings suggest that the hypothesis that dry transport is ancestral in bees should be reexamined.
\end{abstract}

Apoidea / glaze / Hesperapis / Perdita / scopae

\section{INTRODUCTION}

Female bees collect pollen at flowers and transport it to the nest where it serves as the primary protein source for their progeny. Although past research has explored the various adaptations of bees to gather pollen (e.g., Thorp 1979; Müller 1996a, b; Müller and Bansac 2004), fewer studies have addressed how pollen is transported to the nest. Although a few bee taxa transport pollen internally in the crop, most transport it either on the ventral metasoma (e.g., most Megachilidae) or, more commonly, on the hind legs (Michener

Electronic supplementary material The online version of this article (doi:10.1007/s13592-016-0489-8) contains supplementary material, which is available to authorized users.

Corresponding author: Z. Portman, zportman@gmail.com

Manuscript editor: James Nieh
2007). Transport on the hind legs is facilitated by structural elaborations, mostly of the tibia and basitarsus, to include either hair brushes (scopae) or flattened plates (corbiculae).

Pollen is packed on the hind legs and transported in one of three modes: moistened with nectar or oils (Figure 1a, b), dry (Figure 2c, d), or "glazed," a combination of dry and moist collection (Figure 1c, d). A glazed pollen load is initially packed dry and is then capped with nectar during the latter part of the foraging trip (Thorp 2000; Eickwort et al. 1986; Norden et al. 1992). Although most bee species transport dry pollen, five of the seven bee families also contain genera with species that transport either moistened or glazed pollen: Andrenidae, Apidae, Halictidae, Melittidae, and Stenotritidae (Malyshev 1936; Houston and Thorp 1984; Westerkamp 1996; Thorp 2000; Michener 2007).

The evolutionary sequence of external pollen transport among the three modes is presently 


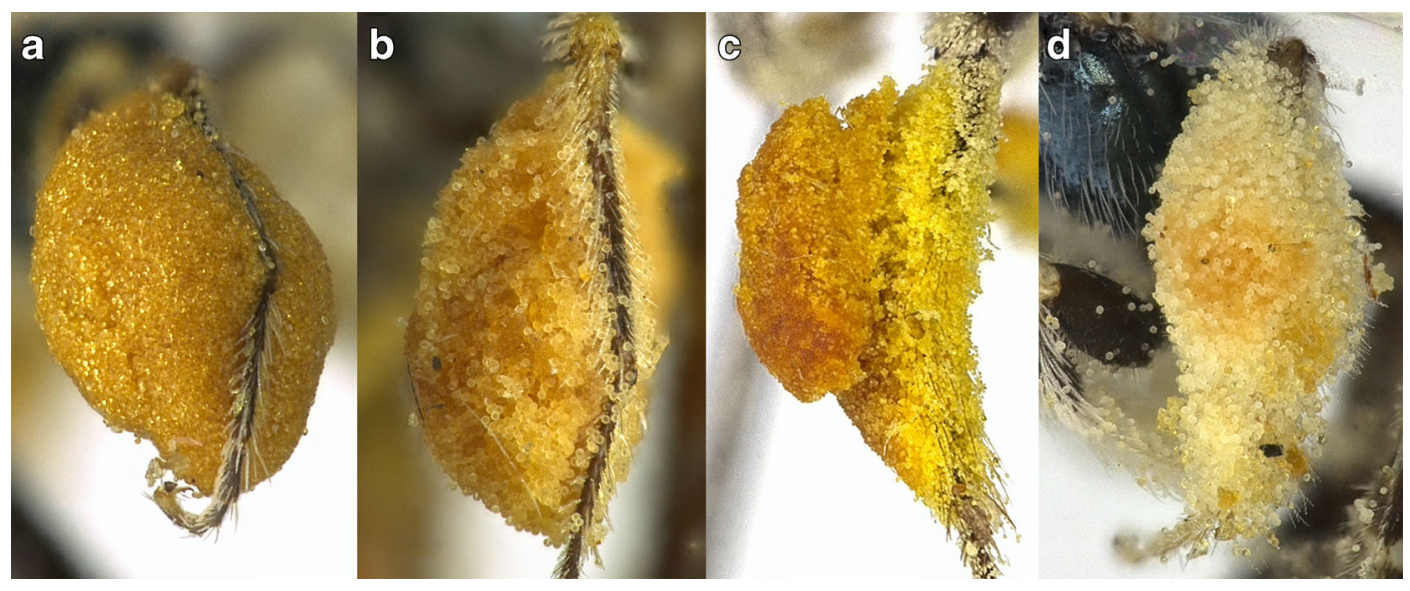

Fig. 1 Lateral views of moist and glazed transport. a Moist transport of Loasaceae pollen by Perdita perplexa Timberlake on simple hairs. b Moist transport of Asteraceae pollen by P. n. sp. 2 aff. laticincta on simple hairs. c Glazed ( $25 \%$ dry) transport of Asteraceae pollen by Hesperapis hurdi Timberlake on branched hairs. d Glazed ( $80 \%$ dry) transport of Asteraceae pollen by P. albonotata Timberlake on corkscrew-shaped hairs.

unsettled. Traditionally, primitive bees were thought to transport pollen internally in the crop (Malyshev 1936; Jander 1976; Michener et al. 1978; Michener 1979). More recent hypotheses propose that primitive bees transported pollen dry on plumose hairs that covered most of the body (Roberts and Vallespir 1978; Radchenko and Pesenko 1996; Michener 2007). This hypothesis is presumably supported by the branched body hairs and plumose hindleg hairs found on the oldest known bee fossil ( $100 \mathrm{Myr})$, a single male Melittosphex burmensis Danforth and Poinar (Danforth and Poinar 2011). Alternatively, others have hypothesized that plumose hairs originated as an adaptation for temperature and water regulation rather than pollen transport (Engel 2001, Michener 2007). The paucity of bees in the fossil record (Michez et al. 2012) offers little additional help in disentangling the evolution of pollen transport or of hair traits.

Bee genera that contain some species that transport moist pollen and others that transport pollen dry are particularly apt to shed light on the evolutionary sequence of pollen transport modes especially when phylogenies are available for comparison. Two examples are the genera Perdita

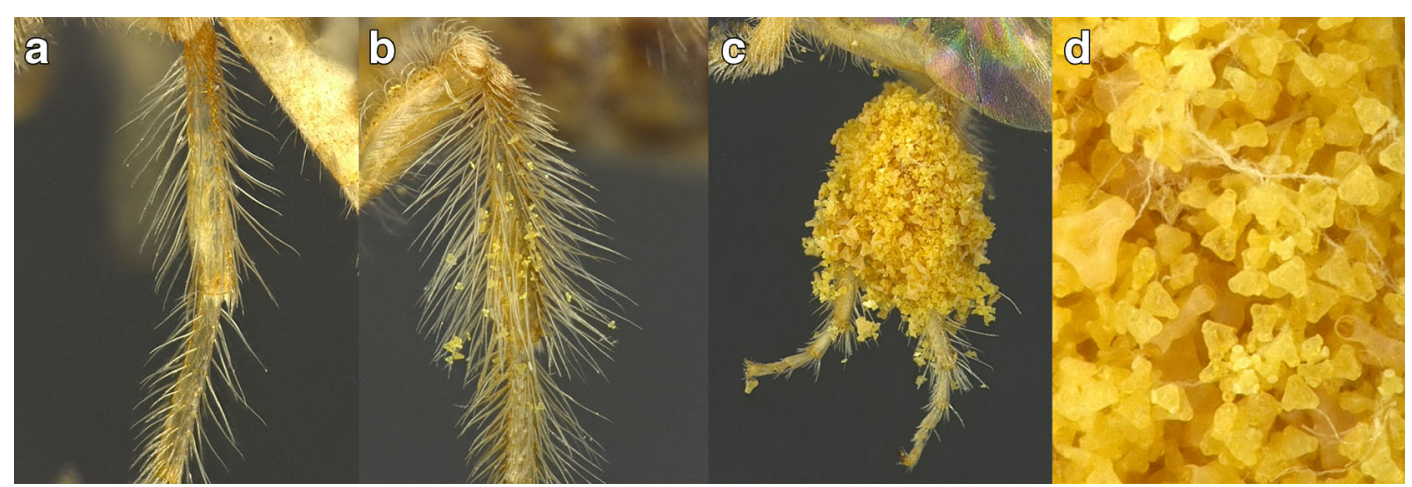

Fig. 2 Dry transport of Onagraceae pollen. a Sparse, simple scopal hairs of P. pallida Timberlake. b Denser and longer scopal hairs of Perdita vespertina Griswold \& Miller. c Dry transport Onagraceae pollen on P. pallida. d Closeup of $\mathrm{c}$ showing viscin threads binding pollen together. 
(Andrenidae) and Hesperapis (Melittidae) (Timberlake 1954; Stage 1966), which are distantly related (Cardinal and Danforth 2013; Hedtke et al. 2013), yet have several similarities: They are restricted to North America (Michener 2007; Michez et al. 2007), are most diverse in the arid west (Michener 2007), and are comprised almost exclusively of oligoleges, i.e., species which use pollen from a small set of related floral hosts (Linsley 1958; Stage 1966; Eickwort and Ginsberg 1980; Cane et al. 1996; Minckley et al. 2013). A recent partial phylogeny is available for Perdita (Danforth 1996) and preliminary ones are available for Hesperapis (Stage 1966; Michez et al. 2009).

At present, the incidence of Perdita species that transport moist, dry, or glazed pollen loads is unknown. Although many are thought to transport a pollen mass that has been continuously moistened with nectar as it is packed onto the hind tibia (Timberlake 1954; Thorp 1979; Michener 2007; Neff 2008), the genus is large ( $>630$ species, Portman et al. 2016) and the transport modes of only seven species have been studied in detail. Of these, six are moist transporters and one transports glazed pollen (Online Resource 1: Table SI). Species that "glaze" their pollen loads are thought to be confined to one monophyletic section of seven subgenera (Danforth 1996; Timberlake 1954; Michener 2007). The pollen transport mode of most Hesperapis ( 40 species, Cane et al. 1996) species is also poorly known; only three, all moist-transporters, have been investigated in depth (Online Resource 1: Table SI).

At least two salient factors may influence pollen transport mode: host plant choice, scopal hair morphology and distribution, or an interaction of the two. Thorp (1979) proposed that moist pollen transport would be particularly advantageous to generalist pollen foraging species because moistening facilitates the agglutination of pollen of diverse shapes and sizes (see also Vaissière and Vinson 1994). Paradoxically, however, many of the species that transport moistened pollen are oligolectic (Thorp 1979). In addition, there are many examples of host plant pollen being collected by different bee species that employ contrasting transport modes (e.g., Hurd and Linsley 1975, Larrea specialists; Hurd et al. 1980, Helianthus specialists). Since both dry and moist transport are exhibited by diverse generalist and specialist pollen foragers on the same host, it suggests that additional factors such as scopal hair characteristics or evolutionary limitations might be germane.

It has been previously suggested that the structure, density, and distribution of the scopae correspond to pollen properties. The scopal hairs associated with dry transport often reflect the size and ornamentation of the pollen specialized on (Linsley 1958; Thorp 1979). Examples include long simple hairs on bees specialized on Onagraceae (Michener 1944; Linsley et al. 1963; Thorp 1969, 1979); hair brushes of long, simple, curved hairs on bees specialized on Cucurbitaceae (Hurd and Linsley 1964); and dense, finely plumose, or branched scopal hairs on bees specialized on small, spiny Asteraceae pollen (Linsley 1958; Linsley and MacSwain 1958; Moldenke 1979). Alternatively, other studies suggest that the simple scopal hairs of moist transporters are adaptable to holding many pollen types (Roberts and Vallespir 1978; Thorp 1979, 2000; Michener 2007). In Perdita, there are clear differences in the structure of the scopal hairs between species that transport moist or glazed pollen; species that transport glazed pollen typically have longer, denser, and more structurally complex scopal hairs (Timberlake 1954; Danforth 1996).

Our objectives here are threefold: (1) expand our knowledge of the distribution of dry, moist, and glazed pollen transport in Perdita and Hesperapis, (2) determine if pollen transport mode is associated with specialization on particular floral hosts or pollen types, and (3) uncover associations between scopal hair types and pollen transport mode. We then use extant though inchoate phylogenies to derive systematic hypotheses which address the origin and evolution of pollen transport.

\section{METHODS}

Specimens in the genera Perdita and Hesperapis were examined from the USDA Pollinating Insect Research Unit (PIRU) collection in Logan, UT and the Entomology Research Museum, University of California, Riverside, CA using a Leica M125 or MZ12 stereomicroscope with a 
Techniquip ProLine 80 LED ring light. A subset of specimens was further examined using a Quanta FEG 650 Scanning Electron Microscope to confirm or refine findings on the distribution and morphology of scopal hairs and pollen grains.

Pollen transport mode was classified into three groups: moist (Figure 1a, b, entire pollen load moistened), dry (Figure 2c, d, no moistening detected), or glazed (Figure 1c, d, an initial layer of dry pollen covered by a layer of moistened pollen). In bees that transport glazed pollen, we estimated the proportion of the pollen load on the tibia and basitarsus that was dry. Some species were represented only by specimens with partially filled dry pollen loads, making it impossible to distinguish between dry and glazed transport. These specimens were classified as transporting initially dry pollen.

We categorized scopal hair type by the location of hairs on different areas of the hind legs, hair length, hair morphology, and the presence of pollen in those hairs. Although hair density and length are continuous rather than discrete characters, we were able to confidently place them into discrete categories. Hair density was estimated based on the space between scopal hairs and was classified into three groups: sparse, medium, or dense, based on whether the integument was clearly visible, partially obscured, or fully obscured, respectively. Hair length was classified as short, medium, or long based on whether the hairs were less than $2 \times$ the maximum width of the hind tibia, between 2 and $3 \times$, or greater than $3 \times$, respectively. We also classified the associated pollen-transporting hairs on the anterior face of the hind tibia as either simple, branched, wavy, or corkscrew-shaped (Figure 3).

We used two steps to determine whether pollen in the scopae was moist or dry: a pollen load was deemed moist-packed if it was compact and extended beyond the scopal hairs. To further confirm the moist-packed designation, an insect pin was used to poke the pollen mass. Moistened pollen in museum specimens hardens into an impervious mass that resists "poking," whereas dry pollen offers no resistance and is readily penetrated. Because pollen in the scopae can be wetted passively when bees are collected in pan traps, malaise traps, or when bees regurgitate nectar in kill jars, we did not survey specimens with signs of wetting on other parts of the body such as matted hairs.

We surveyed a representative subset of species from every subgenus and major species group of the target genera (Online Resource 2: Table SII). Multiple specimens of each species from varying collection locations and times were surveyed whenever possible (Online Resource 1: Table SI). An attempt was made to survey species that collectively specialize on a wide range of floral hosts. Particular attention was paid to bee groups thought to contain species that transport dry or glazed pollen; these groups had all available species surveyed. Records for four species not represented in the PIRU collection by specimens with pollen were compiled from the literature (Online Resource 1: Table SI).

Floral specialization of Perdita and Hesperapis species was compiled from various published sources and visitation records in the PIRU database (US NPID 2016; Online Resource, Table SI). Lastly, scopal pollen of representative specimens was compared to pollen on slides prepared from previous studies in Clark County, NV, and Colorado (Tepedino et al. 1999; Griswold et al. 2006). Morphological terminology and taxonomic classification of Perdita follow Michener (2007), and taxonomic classification of Hesperapis follows Michez et al. (2007) and includes the unnamed species from Stage (1966) and Michener (1981).

\section{RESULTS}

The vast majority of both Perdita and Hesperapis species surveyed are oligolectic, specializing on floral hosts in one of 21 and 9 plant families, respectively (Table I). Most species in both genera transported pollen that had been uniformly moistened with nectar (94 of 136 species of Perdita; 11 of 17 species of Hesperapis ). Dry or glazed pollen transport only occurred in species of both genera that specialized on Asteraceae or Onagraceae pollen.

\subsection{Glazed or dry pollen transport}

Forty-two species of Perdita transported either glazed or dry pollen: 24 glazed, 15 dry at least 

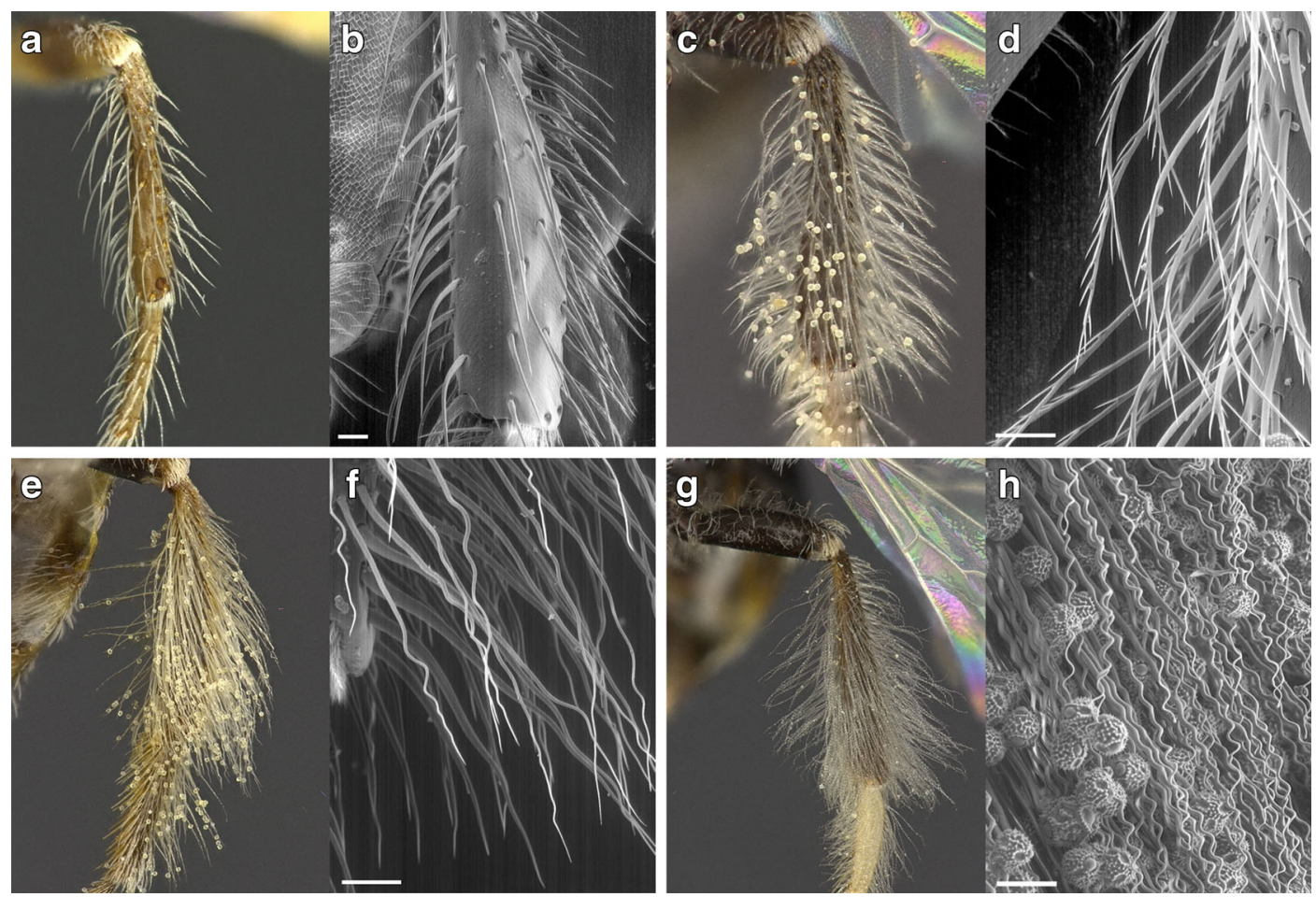

Fig. 3 Optical and SEM examples of the different hair types. a and $\mathbf{b}$ Simple hairs on moist-transporting Perdita koebelei Timberlake. $\mathbf{c}$ and $\mathbf{d}$ Branched hairs on P. asteris Cockerell. $\mathbf{e}$ and $\mathbf{f}$ Wavy hairs on P. lingualis Cockerell and $P$. albovittata Cockerell, respectively. $\mathbf{g}$ and $\mathbf{h}$ Corkscrew-shaped hairs on P. moabensis Timberlake. All SEM scale bars $=50 \mu \mathrm{m}$

initially, and 3 dry (Table I; Online Resource 1: Table SI). Thirty-eight of those 42 species specialize on Asteraceae hosts with the proportion of dry pollen ranging from 25 to $80 \%$. Bees that glaze their pollen loads do not entirely cap the basal layer of dry pollen; instead, moistened pollen is always added at a similar location on the anterior face of the hind tibia and only partially covers the dry pollen (e.g., Figure 1c, d). Of the four species specialized on Onagraceae hosts, three transported dry pollen loads and one transported pollen dry at least initially.

The distribution of glazed and dry pollen transport follows a clear phylogenetic pattern. Although Perdita species in at least 11 subgenera and species groups are specialized on Asteraceae pollen (Online Resource 2: Table SII), the species that transport glazed pollen fall into a single monophyletic group of seven subgenera (Online
Resource 2: Fig. S2; Timberlake 1954; Danforth 1996). In contrast, the 18 surveyed species that transported entirely moist Asteraceae pollen are scattered across at least four unrelated subgenera and species groups: subgenus Pygoperdita (2) and the species groups Octomaculata (9), Ventralis (2), and Zonalis (5) within subgenus Perdita s. s. (Online Resource 2, Table SII). All of the Perdita species specialized on Onagraceae are in the single monophyletic subgenus Xerophasma (Griswold and Miller 2010).

No Hesperapis transported entirely dry pollen: of six species that transported glazed pollen, five specialized on hosts in Asteraceae and one on an Onagraceae host (Table I; Online Resource 1 :Table SI). The proportion of dry pollen in glazed loads ranged from 10 to $25 \%$ for Asteraceae specialists and $50 \%$ for the lone Onagraceae specialist. As with Perdita, moist pollen was added by 
Table I. The number of Perdita and Hesperapis species examined, categorized by host plant family and mode of pollen transport

\begin{tabular}{|c|c|c|c|c|c|c|c|c|c|c|}
\hline \multirow[t]{3}{*}{ Host plant family } & \multicolumn{10}{|c|}{ Transport mode } \\
\hline & \multicolumn{5}{|c|}{ Perdita } & \multicolumn{5}{|c|}{ Hesperapis } \\
\hline & $\mathrm{M}$ & G & $\mathrm{D}$ & DI & SUM & M & G & $\mathrm{D}$ & DI & SUM \\
\hline Amaranthaceae & 1 & & & & 1 & & & & & \\
\hline Aquifoliaceae & 1 & & & & 1 & & & & & \\
\hline Asparagaceae & 1 & & & & 1 & & & & & \\
\hline Asteraceae & 18 & 24 & & 14 & 56 & 1 & 5 & & & 6 \\
\hline Boraginaceae & 7 & & & & 7 & & & & & \\
\hline Brassicaceae & 3 & & & & 3 & & & & & \\
\hline Cleomaceae & 2 & & & & 2 & & & & & \\
\hline Euphorbiaceae & 7 & & & & 7 & & & & & \\
\hline Fabaceae & 11 & & & & 11 & 1 & & & & 1 \\
\hline Fabaceae and/or Zygophyllaceae & 1 & & & & 1 & 1 & & & & 1 \\
\hline Hydrophyllaceae & & & & & & 1 & & & & 1 \\
\hline Lamiaceae & 2 & & & & 2 & & & & & \\
\hline Liliaceae & 3 & & & & 3 & & & & & \\
\hline Loasaceae & 4 & & & & 4 & 2 & & & & 2 \\
\hline Malvaceae & 4 & & & & 4 & 1 & & & & 1 \\
\hline Onagraceae & & & 3 & 1 & 4 & & 1 & & & 1 \\
\hline Papaveraceae & 4 & & & & 4 & & & & & \\
\hline Polemoniaceae & 3 & & & & 3 & 2 & & & & 2 \\
\hline Polygonaceae & 4 & & & & 4 & & & & & \\
\hline Rosaceae & 3 & & & & 3 & 1 & & & & 1 \\
\hline Salicaceae & 2 & & & & 2 & & & & & \\
\hline Solanaceae & 6 & & & & 6 & & & & & \\
\hline Unknown & 2 & & & & 2 & & & & & \\
\hline Zygophyllaceae & 5 & & & & 5 & 1 & & & & 1 \\
\hline Total & 94 & 24 & 3 & 15 & 136 & 11 & 6 & & & 17 \\
\hline
\end{tabular}

$M$ moist, $G$ glazed, $D$ dry, $D I$ dry initially

Hesperapis females atop dry pollen only on the anterior face of the hind tibia and did not evenly cap the dry pollen in the scopa.

\subsection{Hair types}

Pollen transport mode is associated with particular hair types in both Perdita and Hesperapis (Online Resource 2: Table SII; Figure 3). Ninetythree of 94 Perdita species that transport moistened pollen have simple scopal hairs. The exception is one species in the Sphaeralceae Group which transports Fabaceae pollen on minutely branched hairs. Otherwise, the hairs of the moist-transporting Perdita species are remarkably uniform, despite transporting pollen of 20 diverse plant families (Online Resource 2: Table SII). Similarly, all 11 species of Hesperapis that transport moistened pollen have simple scopal hairs that appear to act as generalized anchors for masses of agglutinated pollen; these species specialize on collecting pollen from nine disparate plant families. 
In both Perdita and Hesperapis, glazed transport of Asteraceae pollen is associated with denser and longer hairs compared to those that transport moistened pollen (Online Resources: Tables SII, SI). Perdita species that transport glazed Asteraceae pollen are also more likely to have diverse scopal hair types, including simple, branched, wavy, or corkscrew-shaped (Figure 3); the most common scopal hair type is wavy ( 24 species, 3 subgenera), followed by branched (10 species, 2 subgenera), corkscrew-shaped (3 species, 2 subgenera), and simple (1 species) (Table SII). A $2 \times 2$ contingency table analysis (Maxwell 1961) of hair type (simple vs. elaborate) by transport mode (moist vs. glazed or dry) for Perdita was highly significant $\left(X^{2}=109.2, \mathrm{df}=1\right.$, $P \ll 0.0001)$ : moist and simple hairs are highly associated as are elaborate hairs and glazed or dry transport (Online Resource 2: Table SIII). The Hesperapis species that transport glazed Asteraceae pollen have either branched (4 species) or simple (1 species) hairs (Table SII).

In both Perdita and Hesperapis, dry or glazed transport of Onagraceae pollen is associated with simple scopal hairs, although they are sometimes longer and denser than the scopal hairs of species that transport moistened pollen. Of the four surveyed Perdita species which are Onagraceae specialists, two have scopal hairs whose type, length, and spacing are similar to moist-transporting Perdita species (Figure 2a), although the other two species have longer and denser scopal hairs (Figure 2b).

\subsection{Hair distribution}

The distribution of pollen-transporting hairs on a bee's hind legs also differs between moist and dry or glazed pollen collectors, with scopal hairs of species that transport moist pollen tending to cover a smaller surface area than species that transport dry or glazed pollen. For example, the scopal hairs of Perdita that transport moist pollen are located only on the anterior face of the hind tibia and basitarsus. In contrast, all Perdita examined that transport dry or glazed Asteraceae pollen have pollen-transporting hairs that also cover the lateral and posterior face of the hind tibia, the anterior side of the hind femur, and the anterior face of the hind trochanter (Figure S1_B). The morphology of the scopal hairs on the posterior face of the tibia matches the hairs on the anterior face, but the hairs on the femur and trochanter are always branched, regardless of the hair type on the tibia. Similar to Perdita, all four Hesperapis species that transport glazed Asteraceae pollen have scopal hairs on the posterior face of the hind tibia, and three also have branched hairs on the femur and trochanter of the hind legs. However, the hairs on the femur and trochanter of those Hesperapis are relatively sparse and short compared to Perdita and appear to transport only a dusting of pollen, if any. In both Perdita and Hesperapis species that transport glazed pollen, the expanded scopal hairs on the trochanter, femur, and posterior face of the hind tibia always transport entirely dry pollen; they are never capped with moistened pollen like the scopal hairs on the anterior face of the tibia.

The differences in the distribution of the scopal hairs of bees that collect dry or glazed Onagraceae pollen are relatively minimal compared to those that transport moist pollen. All of the Perdita species that transport dry Onagraceae pollen have an expanded distribution of scopal hairs only on the posterior face of the hind tibia. Similarly, the one species of Hesperapis that transported moistcapped Onagraceae pollen has simple and sparse scopal hairs on the posterior face of the hind tibia, though they are shorter than the hairs on the anterior face.

\section{DISCUSSION}

The distantly related bee genera Perdita (Andrenidae) and Hesperapis (Melittidae) (Cardinal and Danforth 2013; Hedtke et al. 2013) display convergent (Arendt and Reznick 2008) evolutionary patterns of pollen transport. In both genera, most species examined transport completely moistened pollen loads and a minority transport either glazed or dry pollen loads. Those that transport glazed or dry pollen specialize only on floral hosts in the families Asteraceae and Onagraceae, even though Perdita and Hesperapis contain species that specialize on 21 and 9 plant families, respectively (Table I). 
Available evidence suggests that moist pollen transport is ancestral in both genera and that the most probable evolutionary pathway is from moist to glazed or moist to dry. This hypothesis is supported in Perdita by the near ubiquity of moist transport in the subfamily Panurginae (Rozen 1967; Michener 2007), of which Perdita is a member, and by Danforth's (1996) morphological phylogeny for Perdita which shows that glazed and/or dry pollen transport is limited to two derived clades (Online Resource 2: Fig. S2). In addition, subgenera that transport the highest proportion of dry pollen fall in the more derived clades (Danforth 1996). The hypothesis that moist transport is basal in Hesperapis is supported by Stage's (1966) inchoate morphological phylogeny as well as the seven species of Hesperapis included in the molecular phylogeny of Michez et al. (2009). Both phylogenies have the glazed and dry-transporting species limited to derived clades, with glazed transport of Asteraceae and dry transport of Onagraceae likely arising in separate derived clades in Perdita. Overall, the patterns in both genera suggest that they are responding to similar selective pressures.

Evidence also suggests that the evolution of glazed or dry transport in these genera was initiated by a host switch to either Asteraceae or Onagraceae pollen. Host switches to Onagraceae by single clades of Perdita (Xerophasma) and Hesperapis (Panurgomia) do not entail modifications of scopal hairs (Table SII). However, for both bee genera, host switches to Asteraceae are associated with modified scopal hairs. In Perdita, all but one member of the Asteraceae clade exhibits elaborate scopal hairs (corkscrew-shaped, wavy, or branched) that appear derived (Danforth 1996, Table SII, Figure 3). In contrast, moist transport of Asteraceae pollen occurs in four large, species-rich clades of Perdita (subgenus Pygoperdita and the Octomaculata, Ventralis, and Zonalis species groups within subgenus Perdita s.s.), all of which contain species that specialize on a wide variety of other plant taxa and have simple scopal hairs. The pattern is repeated in Hesperapis, with both simple and branched scopal hairs found in Asteraceae specialists, suggesting that more elaborate scopal hairs are recent adaptations for transporting glazed Asteraceae pollen.
The association of Asteraceae or Onagraceae pollen with glazed or dry pollen transport, and more elaborate scopal hairs may be due to the physical properties of the pollen grains, particularly those which may confer an alternative binding mode. Onagraceae pollen in particular has sticky viscin threads that attach the pollen grains together and to the scopal hairs of bees (Linsley 1958; Roberts and Vallespir 1978; Hesse 1981). A similar binding function may be provided by the copious pollenkitt and echinate projections of Asteraceae pollen. Pollen with copious pollenkitt, such as Asteraceae and Malvaceae, is more adhesive than other pollen types and readily attaches passively to foragers in large amounts (Allard 1910; Parker 1981; Buchmann and Shipman 1990; Neff and Simpson 1997; Thorp 2000; Goulson et al. 2005). Pollenkitt's adhesive properties may also be enhanced by pollen sculpturing because spiny or echinate pollen grains can promote adhesion to other pollen grains or other surfaces by increasing the available surface area with which pollenkitt may interact (Roberts and Vallespir 1978; Lin et al. 2013). Pollen spines may also enhance the electrostatic binding potential of pollen (Chaloner 1986; Hesse 2000). Overall, despite being unrelated and dissimilar in morphology, the viscin threads of Onagraceae pollen and the pollenkitt and spines of Asteraceae pollen both provide an alternative to using nectar to bind the pollen grains together and to the scopae.

Although pollen types with spines and copious pollenkitt are effective at attaching to pollinators and to each other, they apparently resist being packed together with nectar by bees. Spines seem to both increase the amount of nectar required to pack individual grains together and decrease the size and stability of the final pollen mass (Vaissière and Vinson 1994). In most instances, moist-transporting bees have difficulty packing, or even reject, pollen types with large spines and copious pollenkitt (Linsley 1960; Stephen et al. 1969; Raine and Chittka 2007; Lunau et al. 2015). In some cases, removing the pollenkitt or bending the spines increases the ability of bees to pack moistened pollen (Lunau et al. 2015). The hypothesis that pollen is kept partially dry primarily for transport purposes is supported by the fact that glazed-transporting Perdita whose nesting 
biology has been studied (P. albipennis, P. boharti, P. coreopsidis, P. graenicheri) still shape the pollen provisions into uniformly moistened spheres but do so in the nest (Danforth 1989; Norden et al. 1992; Parker 1981).

The association of Asteraceae pollen with dry or glazed pollen transport on elaborate scopal hairs is also found in other bee groups. The subfamily Panurginae, which includes Perdita, contains multiple genera with some species that transport dry or glazed asteraceous pollen (Rozen 1989; Michener 2007). Examples include the genus Panurgus, whose members transport dry Asteraceae pollen on wavy scopal hairs (Münster-Swendsen 1970; Rozen 1971), as well as some species of Protandrena and Pseudopanurgus, which transport dry or glazed Asteraceae pollen on branched scopal hairs (Rozen 1967; Danforth 1996). Many apid bees that transport dry pollen on elaborate scopal hairs are strongly associated with Asteraceae pollen collection (e.g., Melissodes, Svastra), especially compared to related groups that transport moistened pollen such as Eucera and Centris (Moldenke and Neff 1974; Eucera: Timberlake 1969; Centris: Aguiar et al. 2003; Roubik and Villanueva-Gutiérrez 2009). Specialization on Onagraceae pollen is also commonly associated with bee genera that transport dry pollen such as Andrena, Melissodes, Sphecodogastra, Megachile, and Diadasia (Thorp 1979).

Historically, internal or dry pollen transport has been thought to be the ancestral state in bees (Michener 1944; Jander 1976; Roberts and Vallespir 1978; Radchenko and Pesenko 1996; Michener 2007). However, our results best fit a hypothesis of Perdita and Hesperapis switching from moist to dry or glazed pollen transport due to the adhesive properties of pollen grains. This hypothesis is strengthened by the absence of apparent switches from dry to glazed or dry to moist and suggests a reconsideration of the evolutionary pathway of pollen transport in bees. For example, Melittidae, which is hypothesized to be the most basal bee family (Cardinal and Danforth 2013), contains multiple moist-transporting genera in addition to Hesperapis, including Macropis, Melitta, and Rediviva (Malyshev 1936; Cane et al. 1983; Whitehead et al. 1984; Michener
2007; Nilsson and Alves-dos-Santos 2009). The major exception, the genus Dasypoda, transports dry pollen on plumose scopal hairs and contains many Asteraceae specialists (Celary 2002; Michener 2007; Michez et al. 2008). The results of our initial investigations suggest that the question of the ancestral state of pollen transport and its evolutionary trajectory be reopened; only additional systematic and behavioral studies will settle this issue.

\section{ACKNOWLEDGMENTS}

We thank Joe Wilson for informative discussion, Terry Griswold, James Pitts, and various anonymous reviewers for helpful comments on the manuscript, Brian Rozick and Harold Ikerd for curatorial help, Doug Yanega, Jaime Pawelek, and Glenn Hall for providing specimens, and the USDA ARS Pollinating Insect Research Unit for general support and access to the insect collection and facilities. This work is supported by a National Science Foundation Graduate Research Fellowship under grant number DGE-1147384, a Utah State University Graduate Enhancement Award, and a Utah State University Ecology Center Research Award. We acknowledge the support from the Microscopy Core Facility at Utah State University for the SEM work.

Authors' contribution ZP came up with the initial idea for the project. ZP and VT designed the project. ZP gathered the data. ZP and VT wrote the manuscript

Evolution convergente du mode de transport du pollen chez deux genres d'abeilles vaguement apparentés $(\mathrm{Hy}-$ menoptera: Andrenidae and Melittidae)

Apoidea / Hesperapis / Perdita / brosse à pollen

Konvergente Evolution einer Pollentransportform in zwei entfernt verwandten Bienengattungen (Hymenoptera: Andrenidae und Melittidae)

Apoidea / Hesperapis / Perdita / Scopa

\section{REFERENCES}

Allard, H.A. (1910) Preliminary observations concerning natural crossing in cotton. J. Hered. 1, 247-261. 
Aguiar, C.M.L., Zanella, F.C.V., Martins, C.F., Carvalho, C.A.L. (2003) Plantas visitadas por Centris spp. (Hymenoptera: Apidae) na Caatinga para obtenção de recursos florais. Neotrop. Entomol. 32 (2), 247-259.

Arendt, J., Reznick, D. (2008) Convergence and parallelism reconsidered: what have we learned about the genetics of adaptation? Trends Ecol. Evol. 23 (1), 26-32.

Buchmann, S.L., Shipman, C.W. (1990) Pollen harvesting rates for Apis mellifera L. on Gossypium (Malvaceae) flowers. J. Kans. Entomol. Soc. 63 (1), 92-100.

Cane, J.H., Eickwort, G.C., Wesley, F.R., Spielholz, J. (1983) Foraging, grooming and mate-seeking behaviors of Macropis nuda (Hymenoptera, Melittidae) and use of Lysimachia ciliata (Primulaceae) oils in larval provisions and cell linings. Am. Midl. Nat. 110 (2), 257-264.

Cane, J.H., Snelling, R.R., Kervin, L.J. (1996) A new monolectic coastal bee, Hesperapis oraria Snelling and Stage (Hymenoptera: Melittidae), with a review of desert and neotropical disjunctives in the southeastern US. J. Kans. Entomol. Soc. 69 (4), 238-247.

Cardinal S., Danforth, B.N. (2013) Bees diversified in the age of eudicots. Proc. R. Soc. Lond. B Biol. Sci. 280 (1755), 1-9.

Celary, W. (2002) The ground-nesting solitary bee, Dasypoda thoracica Baer, 1853 (Hymenoptera: Apoidea: Melittidae) and its life history. Folia Biol. 50, 191-198.

Chaloner, W. (1986) Electrostatic forces in insect pollination and their significance in exine ornament. in: Blackmore, S. and Ferguson, I.K. (Eds.), Pollen and spores: form and function. Academic Press, London, pp. 103-108.

Danforth, B.N. (1989) Nesting behavior of four species of Perdita (Hymenoptera: Andrenidae). J. Kans. Entomol. Soc. 62 (1), 59-79.

Danforth, B.N. (1996) Phylogenetic analysis and taxonomic revision of the Perdita subgenera Macrotera, Macroteropsis, Macroterella, and Cockerellula (Hymenoptera: Andrenidae). Univ. Kans. Sci. Bull. 55 (16), 635-692.

Danforth, B.N., Poinar, G.O. (2011) Morphology, classification, and antiquity of Melittosphex burmensis (Apoidea: Melittosphecidae) and implications for early bee evolution. J. Paleontol. 85 (5), 882-891.

Eickwort, G.C., Ginsberg, H.S. (1980) Foraging and mating behavior in Apoidea. Annu. Rev. Entomol. 25 (1), 421-446.

Eickwort, G.C., Kukuk, P.F., Wesley, F.R. (1986) The nesting biology of Dufourea novaeangliae (Hymenoptera: Halictidae) and the systematic position of the Dufoureinae based on behavior and development. J. Kans. Entomol. Soc. 59 (1), 103-120.

Engel, M. (2001) A monograph of the Baltic Amber bees and evolution of the Apoidea (Hymenoptera). Bull. Am. Mus. Nat. Hist. 259, 1-192.

Goulson, D., Hanley, M.E., Darvill, B., Ellis, J.S., Knight, M.E. (2005) Causes of rarity in bumblebees. Biol. Conserv. 122 (1), 1-8.
Griswold, T., Higbee, S., Messinger, O. (2006) Pollination ecology final report for biennium 2003, Clark County, Nevada (2004-2005). USDA-ARS Bee Biology and Systematics Laboratory, Utah State University, Logan, UT.

Griswold, T., Miller, W. (2010) A revision of Perdita (Xerophasma) Timberlake [sic] (Hymenoptera: Andrenidae). Zootaxa 2517, 1-14.

Hedtke, S.M., Patiny, S., Danforth, B.N. (2013) The bee tree of life: a supermatrix approach to apoid phylogeny and biogeography. BMC Evol. Biol. 13, 138.

Hesse, M. (1981) Pollenkitt and viscin threads: their role in cementing pollen grains. Grana 20, 37-41.

Hesse, M. (2000) Pollen wall stratification and pollination. Plant Syst. Evol. 222 , 1-17.

Houston, T.F., Thorp, R.W. (1984) Bionomics of the bee Stenotritus greavesi and ethological characteristics of Stenotritidae (Hymenoptera). Rec. West. Aust. Mus., 11 (4), 375-385.

Hurd, P.D., Linsley, E.G. (1964) The squash and gourd bees - genera Peponapis Robertson and Xenoglossa Smith - inhabiting America north of Mexico (Hymenoptera: Apoidea). Hilgardia 35, 375-477.

Hurd, P.D., Linsley, E.G. (1975) The principal Larrea bees of the southwestern United States (Hymanoptera: Apoidea). Smiths. Contrib. Zool. 193, 1-74.

Hurd, P.D., LaBerge, W.E., Linsley, E.G. (1980) Principal sunflower bees of North America with emphasis on the Southwestern United States (Hymenoptera, Apoidea). Smithson. Contrib. Zool. 310, 1-158.

Jander, R. (1976) Grooming and pollen manipulation in bees (Apoidea): the nature and evolution of movements involving the foreleg. Physiol. Entomol. 1 (3), 179-194.

Lin, H., Gomez, I., Meredith, J.C. (2013) Pollenkitt wetting mechanism enables species-specific tunable pollen adhesion. Langmuir 29 (9), 3012-3023.

Linsley, E.G. (1958) The ecology of solitary bees. Hilgardia 27 (19), 543-585.

Linsley, E.G. (1960) Observations on some matinal bees at flowers of Cucurbita, Ipomoea and Datura in desert areas of New Mexico and Southeastern Arizona. J. N.Y. Entomol. Soc. 68 (1), 13-20.

Linsley, E.G., MacSwain, J.W. (1958) The significance of floral constancy among bees of the genus Diadasia (Hymenoptera, Anthophoridae). Evolution 12 (2), 219-223.

Linsley, E.G., MacSwain, J.W., Raven, P.H. (1963) Comparative behavior of bees on Onagraceae I. Oenothera bees of the Colorado Desert. Univ. Calif. Publ. Entomol. 33 (1), 1-24.

Lunau, K., Piorek, V., Krohn, O., Pacini, E. (2015) Just spines - mechanical defense of malvaceous pollen against collection by corbiculate bees. Apidologie 46, 144-149.

Malyshev, S.I. (1936) The nesting habits of solitary bees. A comparative study. EOS-Rev. Esp. Entomol. 11 (3), 201-309. 
Maxwell, A.E. (1961) Analysing Qualitative Data. Methuen, London.

Michener, C.D. (1944) Comparative external morphology, phylogeny, and a classification of the bees (Hymenoptera). Bull. Am. Mus. Nat. Hist. 82 (6), 151-326.

Michener, C.D. (1979) Biogeography of the bees. Ann. Mo. Bot. Gard. 66 (3), 277-347.

Michener, C.D. (1981) Classification of the bee family Melittidae with a review of species of Meganomiinae. Contrib. Am. Entomol. Inst. 18 (3), 1-135.

Michener, C.D. (2007) The bees of the world, 2nd edn. Johns Hopkins University Press, Baltimore, MD.

Michener, C.D., Winston, M., Jander, R. (1978) Pollen manipulation and related activities and structures in bees of the family Apidae. Univ. Kans. Sci. Bull. 51 (19), 575-601.

Michez, D., Eardley, C., Kuhlmann, M., Patiny, S. (2007) Revision of the bee genus Capicola (Hymenoptera: Apoidea: Melittidae) distributed in the southwest of Africa. Eur. J. Entomol. 104, 311-340.

Michez, D., Patiny, S., Rasmont, P., Timmermann, K., Vereecken, N.J. (2008) Phylogeny and host-plant evolution in Melittidae s.l. (Hymenoptera: Apoidea). Apidologie 39, 146-162.

Michez, D., Patiny, S., Danforth, B.N. (2009) Phylogeny of the bee family Melittidae (Hymenoptera: Anthophila) based on combined molecular and morphological data. Syst. Entomol. 34 (3), 574-597.

Michez, D., Vanderplanck, M., Engel, M.S. (2012) Fossil bees and their plant associates. In: Patiny, S. (Ed.) Evolution of plant-pollinator relationships. Cambridge University Press, Cambridge, pp. 103-164.

Minckley, R.L., Roulston, T.H., Williams, N.M. (2013) Resource assurance predicts specialist and generalist bee activity in drought. Proc. R. Soc. B Biol. Sci. 280, 20122703.

Moldenke, A.R. (1979) Host-plant coevolution and the diversity of bees in relation to the flora of North America. Phytologia 43, 357-419.

Moldenke, A.R., Neff, J.L. (1974) The bees of California, a catalogue with special reference to pollination and ecological research. Origin and Structure of Ecosystems, Technical Reports 74-1 to 74-6. University of California, Santa Cruz.

Müller, A. (1996a) Convergent evolution of morphological specializations in central European bee and honey wasp species as an adaptation to the uptake of pollen from nototribic. Biol. J. Linn. Soc. 57, 235-252.

Müller, A. (1996b) Host-plant specialization in western Palearctic anthidine bees (Hymenoptera: Apoidea: Megahilidae). Ecol. Monograph. 66 (2), 235-257.

Muller, A., Bansac, N. (2004) A specialized pollen-harvesting device in western palaearctic bees of the genus Megachile (Hymenoptera, Apoidea, Megachilidae). Apidologie 35, 329-337.
Münster-Swendsen, M. (1970) The nesting behaviour of the bee Panurgus banksianus Kirby (Hymenoptera, Andrenidae, Panurginae). Insect Syst. Evol. 1, 93-101.

Neff, J.L. (2008) Components of nest provisioning behavior in solitary bees (Hymenoptera: Apoidea). Apidologie 39, 30-45.

Neff, J.L., Simpson, B.B. (1997) Nesting and foraging behavior of Andrena (Callandrena) rudbeckiae Robertson (Hymenoptera: Apoidea: Andrenidae) in Texas. J. Kans. Entomol. Soc. 70 (2), 100-113.

Nilsson, L.A., Alves-dos-Santos, I. (2009) The oligolectic solitary bee Melitta tricinta Kirby, 1802 (Sw. rödtoppebi) in Sweden (Hymenoptera, Apoidea, Melittidae). Entomol. Tidskr. 130 (2), 85-98.

Norden, B.B., Krombein, K.V., Danforth, B.N. (1992) Taxonomic and bionomic observations on a Floridian Panurgine bee, Perdita (Hexaperdita) graenicheri Timberlake (Hymenoptera: Andrenidae). J. Hymenopt. Res. 1 (1), 107-118.

Parker, F.D. (1981) Sunflower pollination: abundance, diversity and seasonality of bees and their effect on seed yields. J. Apic. Res. 20 (1), 49-61.

Portman, Z.M., Griswold, T., Pitts, J.P. (2016) Association of the female of Perdita (Xeromacrotera) cephalotes (Cresson), and a replacement name for Perdita bohartorum Parker (Hymenoptera: Andrenidae). Zootaxa 4097 (4), 567-574.

Raine, N.E., Chittka, L. (2007) Pollen foraging: Learning a complex motor skill by bumblebees (Bombus terrestris ). Naturwissenschaften 94, 459-464.

Radchenko, V.G., Pesenko, Y.A. (1996) "Protobee" and its nests: a new hypothesis concerning the early evolution of the Apoidea (Hymenoptera). Entomol. Rev. 75 (2), 140162.

Roberts, R.B., Vallespir, S.R. (1978) Specialization of hairs bearing pollen and oil on the legs of bees (Apoidea: Hymenoptera). Ann. Entomol. Soc. Am. 71 (4), 619-627.

Roubik, D.W., Villanueva-Gutiérrez, R. (2009) Invasive Africanized honey bee impact on native solitary bees: A pollen resource and trap nest analysis. Biol. J. Linn. Soc. 98 (1), 152-160.

Rozen, J.G. (1967) Review of the biology of panurgine bees, with observations on North American forms (Hymenoptera, Andrenidae). Am. Mus. Novit. 2297, 1-44.

Rozen, J.G. (1971) Biology and immature stages of Moroccan panurgine bees (Hymenoptera, Apoidea). Am. Mus. Novit. 2457, 1-37.

Rozen, J.G. (1989) Life history studies of the primitive panurgine bees (Hymenoptera: Andrenidae: Panurginae). Am. Mus. Novit. 2962 , 1-27.

Stage, G.I. (1966) Biology and systematics of the American species of the genus Hesperapis Cockerell. Unpublished D. Phil. Thesis, University of California, Berkeley.

Stephen, W.P., Bohart, G.E., Torchio, P.F. (1969) The biology and external morphology of bees, Agricultural Experiment Station, Oregon State University, Corvalis. 
Tepedino, V.J., Sipes, S.D., Griswold, T.L. (1999) The reproductive biology and effective pollinators of the endangered beardtongue Penstemon penlandii (Scrophulariaceae). Plant Syst. Evol. 219 (1), 39-54.

Thorp, R.W. (1969) Systematics and ecology of the bees of the subgenus Diandrena (Hymenoptera: Andrenidae). Univ. Calif. Publ. Entomol. 52 , 1-146.

Thorp, R.W. (1979) Structural, behavioral, and physiological adaptations of bees (Apoidea) for collecting pollen. Ann. Mo. Bot. Gard. 66 (4), 788-812.

Thorp, R.W. (2000) The collection of pollen by bees. Plant Syst. Evol. 222 (1-4), 211-223.

Timberlake, P.H. (1954) A revisional study of the bees of the genus Perdita F. Smith, with special reference to the fauna of the Pacific Coast (Hymenoptera, Apoidea) Part I. Univ. Calif. Publ. Entomol. 9 (6), 345-432.

Timberlake, P.H. (1969) A contribution to the systematics of north American species of Synhalonia (Hymenoptera, Apoidea). Univ. Calif. Publ. Entomol. 57, 1-76.
US NPID (2016) U. S. National pollinating insects database, US Department of Agriculture, Agriculture Research Service, Bee Biology and Systematics Laboratory, Logan, Utah. (accessed June 2016).

Vaissière, B.E., Vinson, S.B. (1994) Pollen morphology and its effect on pollen collection by honey bees, Apis mellifera L. (Hymenoptera: Apidae), with special reference to upland cotton, Gossypium hirsutum L. (Malvaceae). Grana 33, 128-138.

Westerkamp, C. (1996) Pollen in bee-flower relations: some considerations on melittophily. Bot. Acta, 109, 325-332.

Whitehead, V.B., Schelpe, E.A.C.L.E., Anthony, N.C. (1984) The bee, Rediviva longimanus Michener (Apoidea: Melittidae), collecting pollen and oil from Diascia longicornis (Thunb.) Druce (Scrophulariaceae). S. Afr. J. Sci. 80, 286. 